2. Centers for Disease Control, Immunization Practices Advisory Committee. Recommendations for protection against viral hepatitis. MMWR 1985;34:313-35

3. Szmuness W. Stevens CE, Zang EA, Harley EJ, Kellner A. A controlled clinical trial of the efficacy of the hepatitis $B$ vaccine (Heptavax B): a final report. Hepatology 1981;1:377-85

4. Francis DP, Hadier SC, Thompson SE, et al. The prevention of hepatitis $B$ with vaccine. Report of the Centers for Disease Control multi-center efficacy trial among homosexual men. Ann Intern Med 1982;97:3626

5. Rumley RL, Chapman SW. Hepatitis B vaccination of high-risk hospital employees and hemodialysis patients. Abstracts of the 1984 Interscience Conference on Antimicrobial Agents and Chemotherapy, Washington, D.C. October 1984; p 104

6. Schaaff DM, Lender M, Snedeker P. Graham LA. Hepatitis B vaccine in a hospital. Ann Intern Med 1984:101:720-21

7. Centers for Disease Control. Suboptimal response to hepatitis $B$ vaccine given by injection into the buttock. MMWR 1985;34:105-13

8. Pead PJ, Saeed AA, Hewitt WG, Brownfield RN. Low immune responses to hepatitis B vaccine among healthy subjects. Lancet 1985:1:1152

9. Weber DJ. Rutala WA. Samsa GP, Santimaw JE, Lemon SM. Obesity as a predictor of poor antibody response to hepatitis $B$ plasma vaccine. JAMA 1985;254:3187-9

10. Joklik WK. Willett HP. Amos DB (eds). Zinsser microbiology. Norwalk, Cn: Appleton-Century-Crofts, 1984

11. Cockshott WP, Thompson GT, Howlett LJ, Seeley ET. Intramuscular or intralipomatous injections. N Engl J Med 1982:307:356-8

12. Weber DJ, Rutala WA, Samsa GP. Bradshaw SE, Lemon SM. Obesity, not site of immunization, is the key predictor of a poor antibody response to the hepatitis $B$ plasma vaccine. Submitted for publication.

13. Lane TW, Tashjian LS. Ivey F, Gerner H, Via BE. Immunogenicity of hepatitis B vaccination in hospital employees: predicators of seroconversion. Abstracts of the 1985 Interscience Conference on Antimicrobial Agents and Chemotherapy, Minneapolis, October 1985, p 94

14. Jacobson IM, Dienstag JL. Viral hepatitis vaccines. Annu Rev Med 1985:36:241-61

15. Craven DM, Kunches LM, Dienstag JL, et al. Analysis of nonresponsiveness to hepatitis B vaccine in health care workers. Hepatology 1984:4:1077

16. Nowicki MJ, Tong MJ, Bohman RE. Alteration in the immune response of nonresponsers to the hepatitis B vaccine. J Infect Dis 1985:152:12458

17. Miller KD, Gibbs RD, Mulligan MM, Nutman TB, Francis DP. Intradermal hepatitis $B$ vaccine: immunogenicity and side-effects in adults. Lancet $1983: 2: 1454-6$

18. Zoulek G. Lorbeer B. Jitg W. Dienhardt F. Evaluation of a reduced dose of hepatitis B vaccine administered intradermally. J Med Virol $1984 ; 14: 27-32$

19. Redfield RR, Innis BL, Scott RMc, Cannon HG, Bancroft WH. Clinical evaluation of low-dose intradermally administered hepatitis $B$ virus vaccine. JAMA 1985;254:3203-6

20. Centers for Disease Control, Immunization Practices Advisory Committee. Rabies prevention. MMWR 1984;33:393-408

21. Bernard KW, Roberts MA, Summer J. et al. Human diploid cell rabies vaccine: effectiveness of immunization with small intradermal or subcutaneous doses. JAMA 1982;247:1138-42

22. Osterholm MT, Garayalde SM. Clinical viral hepatitis B among Minnesota hospital personnel. JAMA 1985:254:3207-12

\title{
The General Internist and Occupational Medicine
}

IMAGINE that the scope of general internal medicine suddently doubled, creating $\alpha$ plethora of new research topics, practice opportunities, and challenging cases. Imagine that a demographic shift suddenly meant that large numbers of young adults needed primary care services and gave the problems of geriatrics a new dimension. Imagine that $\alpha$ new and different approach to disease prevention and health promotion opened itself to the internist.

There is a field of medicine that holds out such exciting possibilities. It exists largely in the shadows of medical practice, visible to general internists only in fleeting glimpses yet affecting most of their patients from young adulthood and adolescence to well beyond retirement age. It is a discipline of medicine that overlaps much of general internal medicine in content yet incorporates highly specialized knowledge and approaches to solving problems. It is a mode of medical practice that involves unique and often difficult challenges but contains elements of practice that most internists use every day. It is a distinct medical specialty in form and content but one with so few credentialed specialists that internists now and for years to come will handle more cases in the specialty than the specialists themselves. This branch of medicine is occupational medicine, and it is full of opportunity for general internal medicine..$^{1.2}$

This is so because occupational medicine, like internal medicine, is concerned with adults, both while they are of working age and into their retirement. Most adults spend a third of their waking hours at work, and social psychologists have shown that work (or the lack of it) is a critical element in a person's life, identity, and self-esteem. ${ }^{3,4}$ This is an aspect of the patient's life that the general internist can ill afford to ignore, because work plays an important role in health and the patient's health has important implications for work.

The organized specialty of occupational medicine is now at a crossroads - actually a crisis because the supply of trained and interested physicians falls far short of demand. ${ }^{5}$ A great expansion in the demand for occupational health services has led to a much greater involvement of other medical specialists and of primary care practitioners, including internists.

After months of deliberation, the American College of Physicians in 1984 adopted a position paper on the internist and occupational medicine. ${ }^{6}$ This important paper, summarized in the November 1984 issue of the ACP Observer, emphasizes two main points: Internists should be responsive to the occupational health needs of their patients and should be prepared to identify occupationallyassociated disorders and health concerns. Physicians are also judged to have a responsibility to improve health standards by supporting and participating where possible in the prevention of occupational disorders. The internists' role in 
occupational medicine should also include interpreting the implications of a disorder for the patient's livelihood, on important aspect of practice overlooked by the ACP report. The ACP document represents the most significant step thus far in recognizing the validity of an occupational medicine component in general internal medicine practice.

Internists who have approached occupational medicine in a spirit of inquiry and discipline have found many opportunities for research and for $a$ satisfying and demanding practice, particularly in academic and group practice settings. The key to success in this effort, however, is a willingness to learn the specific technical content of occupational medicine and to recognize the existing structure and institutions of the field.?

Occupational medicine today can be excellent and stimulating internal medicine. ${ }^{8}$ The medical content of occupational medicine specialty practice overlaps that of general internal medicine to a large extent. Occupational medicine incorporates substantial content from epidemiology, toxicology, oncology, immunology, and health policy. Preventive medical services and health promotion programs in the workplace complement SREPCIM's recent call for increased emphasis on preventive services in clinical settings. ${ }^{9}$ Evaluating the health hazards in a particular plant or industry, managing $\alpha$ case of $\alpha$ toxic exposure in $\alpha$ workplace setting, and designing and managing employee assistance programs are all common functions of an occupational physician which have no counterpart in general internal medicine practice and require special training for the physician engaged in them. Occupational medicine research particularly has burgeoned in recent years and has grown increasingly sophisticated. ${ }^{8}$

As both an internist and an occupational physician, I have come to believe that formal interaction between representatives of the two specialties is a logical next step in the evolution of both.

How can this be accomplished? To begin, general internists as individuals and through their specialty organizations might consider the following suggestions:

1. Become aware of appropriate standards of practice, legal reporting requirements, and souces of assistance in dealing with occupational injuries and illnesses as they are likely to present in a general internal medicine practice

2. Take the lead in assuring the quality of services provided within so-called "industrial medicine clinics" when practicing in such settings $s^{7} 10$
3. Support continuing education programs suitable for internists in the field

4. Develop groups of general internists who will become knowledgeable on the issues and able to respond with reasoned public statements on major issues involving occupational diseases, workers' compensation reform, environmental health, toxicology, toxic substances incidents, and the delivery of occupational health services

5. Survey the occupational medicine content of internal medicine training and identify ways of strengthening the preparation of internists without overloading the existing training experience

6. Enter into a dialogue with organizations representing occupational medicine and preventive medicine to explore areas of cooperation and issues of mutual interest

General internists may choose to incorporate a limited component of occupational medicine into their practices or research, and a few may enter occupational medicine practice as a major commitment. To be professionally rewarding, however, this must be done with the same methodical preparation and conscious discipline that the internist customarily applies to all subspecialty components of practice and that has traditionally characterized general internal medicine as a field. Tee L. Guidotti, MD, MPH, CCBOM, FACP, Professor of Occupational Medicine and Medicine, The University of Alberta Faculty of Medicine, Edmonton, Alberta T6G 2G3, Canada

\section{REFERENCES}

1. Rosenstock L. Occupational medicine: too long neglected. Ann Intern Med 1981:95:774-6

2. Guidotti TL. Occupational medicine at a crossroads. ACP Observer (January) $1984: 4: 5$

3. Brown JAC. The social psychology of industry. London: Penguin, 1954, printed 1980

4. Special Task Force to the Secretary of Health, Education, and Welfare. Work in America. Cambridge: MIT Press. 1973

5. Graduate Medical Educational National Advisory Committee. GMNAC summary report. Hyattsville, Maryland: Health Resources Administration, U.S. Department of Health and Human Services, 1980

6. ACP Department of Health and Public Policy. Role of the internist in occupational medicine: a position paper on the American College of Physicians. Philadelphia: American College of Physicians, 14 September. 1984

7. Guidotti TL, Kuetzing BH. Competition and despecialization: an anaIytical study of occupational health services in San Diego, 1974-1984. Am J ind Med 1985;

8. Cullen MR. Occupational medicine. A new focus for genera! internal medicine. Arch Intern Med 1985:145:511-5

9. Preventive Health Care Committee, Society for Research and Education in Primary Care Internal Medicine. Preventive medicine in general internal medicine residency training. Ann Intern Med 1985;102:859-61

10. Guidotti TL, Desirable characteristics of the teaching occupational medicine clinic. J Occupat Med 1984:26:105-9 